\title{
Insight to Impact: The Effect of Protean Career Attitude on Employability Perceptions of IT Professionals
}

\author{
P. M. Nimmi ${ }^{\mathrm{a}} \bowtie$, K. A. Zakkariya ${ }^{\mathrm{a}}$, Reyza Nezrin ${ }^{\mathrm{a}}$ \\ ${ }^{a}$ School of Management Studies, CUSAT, India
}

\begin{abstract}
In the contemporary career-scape, protean career attitude is considered as an innovative approach of employees to channel their aspirations independently and to explore their future career prospects on their own. The accelerating rate of change in the nature and types of work necessitates the development of a protean attitude, which in turn will have an impact on the employability perceptions of employees. This study postulates that protean career attitude positively influences internal and external dimensions of employability, and this influence is mediated by career insight, i.e., greater goal clarity and deeper understanding of one's skills and interest. The proposed hypotheses were tested among software engineers employed in the Information Technology (IT) industry and the results indicated that protean attitude predicted both internal employability and external employability, and career insight partially mediates the associations. The study further discusses the importance of employeecentric work culture to retain protean talents.
\end{abstract}

Keywords: Career Insight, External Employability, Internal Employability, Perceived Employability, Protean Career Attitude

Received:

21 November 2019
Accepted revised version:

11 March 2020
Published:

30 June 2020

Suggested citation: Nimmi, P. M., Zakkariya, K. A., \& Nezrin, R. (2020). Insight to impact: The effect of protean career attitude on employability perceptions of IT professionals. Colombo Business Journal. 11(1), 1-23.

DOI: http://doi.org/10.4038/cbj.v11i1.55

(C2020 The Authors. This work is licenced under a Creative Commons Attribution 4.0 International Licence which permits unrestricted use, distribution, and reproduction in any medium, provided the original work is properly cited.

凶nimmimohandas1985@gmail.com: (iD) https://orcid.org/0000-0002-8750-6500 


\section{Introduction}

Changes in the nature of work and the composition of workforce that comes with access to technology and innumerable global opportunities have forced organisations to rethink their traditional structure of and approach to employee management, thus affecting long term employment relationships (Lin, 2015). In response to this change, employees are adopting new forms of career management and career progression strategies to improve their chances of achieving career success. Among them, the protean career concept (Hall, 1996) has been characterised as having a career orientation driven by values as defined by an individual and career management approach that is directed according to those personal values. Several researchers have shed light on the importance of the protean career concept, and its role as a driver of career success (De Vos \& Soens, 2008; Gubler et al., 2014; Hall, 1996) and new insights are coming up in recent literature (Cortellazzo et al., 2020; Rodrigues et al., 2019; Sultana \& Malik, 2019; Redondo et al., 2019). A growing interest in this area stems from the fact that a protean mind set is essential in shaping perceptions and building confidence of employees when the job market is highly dynamic and unpredictable. Every employee prefers to make use of the vibrant economic environment when ample opportunities are available in the labour market and aspire to qualify as a protean talent. "Protean talents usually have a strong protean mindset that allows them to work with numerous organisations throughout their career in transactional relationships, which allows them to remain employable and valuable to current and future employers" (Lin, 2015, p.754). A person with a protean career attitude does not usually follow an idealised career path that is limited by corporate mandates. Hence, due to the flexible and self-directed approach to career progression, such individuals can take risk in an uncertain career scenario (Gubler et al., 2014). Adopting a protean career has several positive career outcomes such as career success (De Vos \& Soens, 2008; Gubler et al., 2014), organizational commitment (Khan et al., 2016); job search activity (Waters et al., 2014) and employee wellbeing ( $\mathrm{Li}, 2018)$.

Individuals with a protean mind set constantly equip themselves with skills and knowledge required to be competitive in the job market, which leads to enhanced employability. A flexible and adaptable attitude on career could enhance one's perception of gaining employment, remaining employable and to switch work places if needed. Perceived employability, which is a subjective evaluation of employability - is defined as "how easy (or difficult) people believe it would be for them to get a new employment" (Berntson, 2008, p.11). Assessing perceptions is 
important as perceptions, rather than reality, triggers cognitions, behaviour, and psychological functioning (Vanhercke et al., 2014). Previous studies have identified some mediators linking protean attitude and perceived employability such as career self-management (De Vos \& Soens, 2008) and learning goal orientation (Lin, 2015). Along with career management behaviours, development of career insight is vital in making suitable career choices (De Vos \& Soens, 2008; Eby et al., 2003).

Although perceived employability is a construct that has two dimensions, internal and external (Rothwell \& Arnold, 2007), most of the previous studies on perceived employability and its relationship with various outcomes have considered perceived employability as a single construct. According to the Rothwell and Arnold (2007), internal employability is the perceived value of the occupation with the current employer or within the labour market whereas external employability reflects the perceived value of employment in the external labour market. Several factors differently influence internal and external employability. Training and job experience influenced internal employability rather than external employability (Groot \& De Brink, 2000), while interpersonal relationship and higher educational qualifications impacted external rather than internal employability (Mincer, 1991). Hence, to have a complete understanding of employability, further studies need to be undertaken that focuses on analysing the impact of these two dimensions of employability.

To the best of the researchers' knowledge, no empirical study has been conducted to explore the development of protean career attitude and its impact on both internal and external employability along with the mediating effect of career insight, even though these concepts are of focal interest to the emerging IT economy like India. Therefore, the present study is undertaken to understand the relationship between protean career attitude and internal/external employability. Additionally, this study seeks to explain whether career insight mediates the relationship between protean career attitude and perceived employability (internal and external). Last, the study focusses on understanding whether career insight has a specific role in augmenting the external employability of employees when compared to their internal employability perceptions.

\section{Literature Review and Hypothesis Development}

\section{Protean Career Attitde and Perceived Employability}

Originally conceptualised by Hall (1996), protean career attitude is a positive psychological factor used by protean talents in their pursuit of psychological career 
success. Protean career attitude is based on an individual's attitude toward career management (Briscoe \& Hall, 2006; Hall, 2002) and is charecterised by two dimensions, value-driven career orientation and self-directed career management. Individuals with a protean mindset tend to use their personal values to navigate through their career, rather than aligning to organisational values and they are selfdirected in managing their vocational behaviour (Hall, 2004). A protean talent is characterised by individuals who are comfortable with forming an active careeroriented relationship across organisational boundaries otherwise known as psychological mobility (Briscoe \& Hall, 2006) and also prefer a career that calls for actual movement between jobs i.e., physical mobility (Briscoe et al., 2006). Empirical studies proved that protean career attitude is positively associated with many work-related outcomes like career growth, career success, and job improvement (Kiong \& Yin-Fah, 2016; Volmer \& Spurk, 2011; Waters et al., 2014 ). Protean attitude can be explained as the 'demand' part of Job Demands Resource model (Bakker \& Demerouti, 2007) that has been developed to cope with work requirements, which in turn motivate employees to gain more resources through self-development or external resources.

In a period of extreme vulnerability to changes in the world of work, individual's perception of being employable becomes essential, as the perception of a situation can affect their behaviour, reactions, and thoughts positively or negatively. Perceived employability (PE) is an individual's perception of his/her possibilities of getting new, equal or better employment (Berntson, 2008). PE is considered as an employee asset or resource, which enables him/her to face the labour market opportunities with more confidence as well as promotes a feeling of well-being and control of one's career (De Cuyper et al., 2011). Perceived Employability is considered as an important factor in line with the Job DemandsResource model (JD-R) (De Cuyper et al., 2011) and Conservation of Resource theory (COR) (Kirves, 2014). Employability perceptions focus on an individual's self-assessment of his/her competency, which is derived from their behavioural competencies skills, knowledge of the labour market, and adaptability (Ngo et al., 2017. Studies indicate that enhanced perceptions of employability could lead to improved job outcomes like improved ability to adapt to changing work environment, job search behaviours, subjective well-being, and health (Berntson, 2008; Chen \& Lim, 2012). The components of perceived employability in a work setting, i.e., internal and external employability denote two different aspects. External employability denotes the ability and willingness to move to a similar or another job in another firm, while internal employability refers to a worker's 
willingness to remain employed with the current employer (Juhdi et al., 2010). The professional attachment of an employee depends on the extent to which his/her profession is valued in an internal job setting or external labour market. Research showed that protean attitude influences protean talents to move across organisational boundaries to follow their self-driven career (Hall, 1996; Hall \& Moss, 1998; Lin, 2015) and specifically protean talents with a higher degree of protean attitude have greater external employability than internal employability (Lin, 2015).

In line with COR theory and JD-R model, individuals with a higher protean career attitude tend to be self-motivated to develop resources that enhance their job market opportunities, which in turn positively influence their employability perceptions. Protean career attitude and its consequences could be explained from the perspective of JD-R model (Bakker \& Demerouti, 2007). According to the JD-R model, any work setting consists of job demands and job resources. Protean orientation acts as a job demand in work setting that requires employees to make efforts to accomplish those resources (Li, 2018). These resources are gained in line with the internal compass of the individuals (i.e. their career goal). Driven by the protean demand, appropriate career planning is devised, which helps in the development of many resources ( $\mathrm{Li}, 2018)$. This vigilant career planning develops their social, human and psychological resources $(\mathrm{Li}, 2018)$ and creates a 'resource caravan' (Kirves, 2014), thereby enhancing a major resource - the 'perception' of their employability. Perceived employability is regarded as a personal resource, according to the COR theory (Kirves, 2014). The employability perceptions could be internal or external, depending on the career goal and market opportunities as perceived by the employee. In a highly dynamic industry like the Indian IT industry it really arouses the curiosity of authors to see whether employees with protean career attitude predict external employability or internal employability. Based on the literature review, we put forward the following hypotheses:

$\mathrm{H}_{1}$ : Protean attitude positively impacts internal employability.

$\mathrm{H}_{2}$ : Protean attitude positively impacts external employability.

\section{The Mediating Role of Career Insight}

Career self-management (CSM) behaviour exerts predominant influence on employee's career development. Of the two types of career management behaviours, reflective and behavioural, career insight constitutes the reflective 
component. Major career outcomes such as perceived employability and career satisfaction are predicted by the reflective component of CSM (Paradnike et al., 2016). Career self-management acts like an internal compass guiding individuals' career orientation (protean career) and employability perceptions that enable them to be capable of adapting to new opportunities and unexpected developments.

Career insight $(\mathrm{CI})$ can be projected as an employee's realistic perception of themselves in the work enviornment (London, 1993) i.e. realism and clarity with which individual pursue his/her goal. From a motivation viewpoint, career insight could be explained as the factor that provides direction for motivation, i.e. the energising or arousal component that encourages his/ her involvement in career planning and decisions (Noe et al., 1990). Career insight strengthens the employability orientations of individual because it enhances knowledge of one's strength and weaknesses and establishes a clear and realistic career goal, by which they can assess their employability and future plans (Clarke, 2008). Career insight, which stems from career motivation theory (London, 1993) is the clear and realistic knowledge about career goals and it could influence the employment preference of workers within the organisation or outside the organisation. Individuals high on career insight usually align their goals in line with the opportunities available in the market (Eby et al., 2003). As protean attitudes reflect a value driven and selfdirected career orientation justified by internal motivation, they are bound to have a stronger sense of career insight characterised by individual career self-management that guides them to make meaningful career decisions (De Vos \& Soens, 2008) and ultimately achieve career success. Another reason why the relationship between protean career attitude and perceived employability should be visible through career insight is because career identity resources (individual's realistic understanding of self) will augment the self-directed and value-driven career orientation to enhance his/her employability perceptions in the labour market.

The impact of career insight on employability perceptions has been theoretically and empirically discussed and supported (Eby et al., 2003; De Vos \& Soens, 2008). However, empirical findings on the role of career insight as a mediator in the relationship between protean career and employability have not been explored so far. Only two studies have been conducted on the probable interaction effect of career insight and protean attitude. Eby et al. (2003) investigated possible interaction effect of protean career attitude and career insight on career success among 458 alumni from South Eastern University. The study does not single out the effect of career insight as the construct was studied in combination with other 
variables like proactive personality and openness to experience. Yet another work that discusses the constructs under study is an empirical analysis by De Vos and Soens (2008). In their paper, the authors studied the mediating effect of career insight in the relationship between protean attitude and career success and found that career insight fully mediated the relationship. Thus so far, no studies have analysed the differentiating effect of career insight on internal and external employability separately.

Accordingly, we hypothesise,

$\mathrm{H}_{3}$ : Career insight mediates the relationship between protean attitude and perceived external employability.

$\mathrm{H}_{4}$ : Career insight mediates the relationship between protean attitude and perceived internal employability.

Based on the above hypotheses, the conceptual model in Figure 1 is framed, with constructs perceived internal employability (IE), external employability (EE), career insight $(\mathrm{CI})$ and protean career attitude (PCA), which is tested in the succeeding sections.

\section{Figure 1: Conceptual Model}

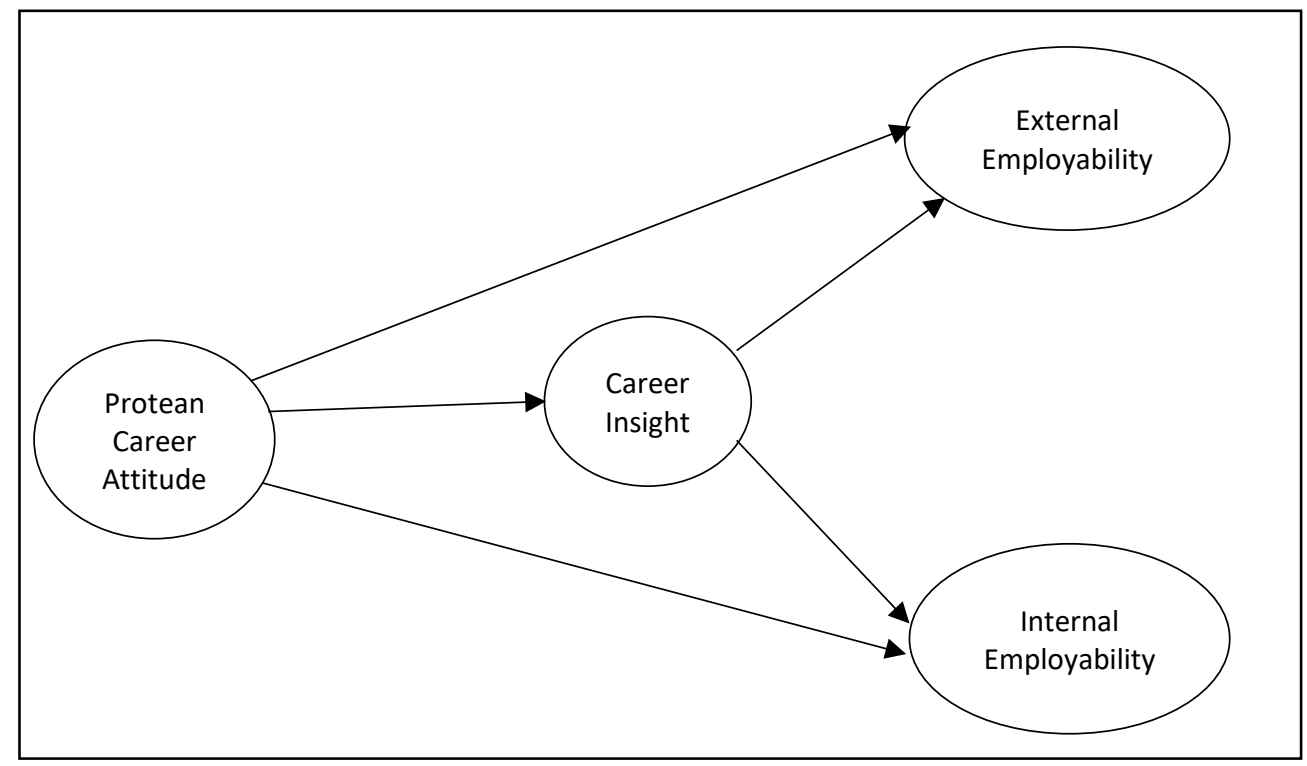




\section{Measures}

The variables presented in Figure 1 were operationalised in the study in the following manner.

Protean career attitude. This was measured with a 14-item scale developed by Briscoe et al. (2006). The scale contained two dimensions: self-directed career orientation with eight items and values-driven career management with six items. A sample item in the dimension of self-directed career management was "when development opportunities have not been offered by my company, I have sought them out on my own." A sample item in the dimension of values-driven career attitude management was "I navigate my own career, based on my personal priorities, as opposed to my employer's priorities." All items were rated on a fivepoint Likert scale ( $1=$ strongly disagree, $5=$ strongly agree). The reliability of the scale has been checked using Cronbach's $\alpha$ in the sample collected and found to be reliable as the value was 0.77 .

Career insight. Career insight was measured with seven items that were adapted from the Career Insight Scale developed by London (1993). Using a 5-point Likert scale, respondents indicated the degree to which they had a better insight into their own career aspirations, skills and personality (e.g. "I have obtained a better insight into what I find important in my career"). The reliability of the instrument has been checked using Cronbach's $\alpha$ in the sample collected, and the value found to be 0.81 which indicates the instrument was reliable.

Perceived employability (perceived internal employability and perceived external employability). This study used the Rothwell and Arnold (2007) self-perceived employability scale to assess employability. The first dimension was the perceived value of occupation in the current organisation (internal employability) with four items. A sample item was "even if there was downsizing in this organisation, I am confident that I would be retained." The other dimension was the perceived value of occupation outside the current organisation (external employability) with six items. A sample item was "I could easily get a similar job to mine in almost any organisation." This scale employed a five-point Likert scale (1=strongly disagree, $5=$ strongly agree). The reliability of the instrument has been checked using Cronbach's $\alpha$ in the sample collected, and the value found to be 0.76 for external employability and 0.70 for internal employability, which shows, the instrument was reliable. 


\section{Methods}

\section{The Research Site: Characterising Protean Careers in The Indian IT Industry Context}

Careers among the IT work force are more diverse than it is in other sectors. Employees working in such a work environment are required to develop an individual identity which will aid them to move through the job market when and where necessary. In this context, developing a protean attitude will help employees who are working in a dynamic industry like the IT industry, to make career choices that lead to subjective career success (De Vos \& Soens, 2008). Studies in the IT sector from the skills transferability perspective has revealed that IT professionals have accumulated enough human capital in their profession to enable them to transfer skills to other organisations within the profession (Mithas \& Krishnan, 2008). The IT industry has the peculiarity that the organisations provide an opportunity for employees to explore multiple occupations within an organisation as part of job structure (Ortega, 2001). The Indian IT sector experiences rapid changes and innovations which provides scope for a protean employee to explore the innumerable opportunities available to them on their own (Gulyani \& Bhatnagar, 2017). Joseph et al. (2012) have found that organisational mobility is the highest for the IT industry. The study also reveals that career mobility of IT professions has helped employees to leverage their general human capital to augment themselves to 'key managerial positions'. In spite of the vast changes occurring in the field, very few studies have come up looking into changing career attitude of employees (Gulyani \& Bhatnagar, 2017; Soumyaja et al., 2018) and its impact on life and career outcomes.

The IT industry of India is a particularly good context to study this phenomenon. The sector has been a significant contributor to the economic growth in India, and has emerged as the largest private- sector employer (Upadhyay et al., 2016). Global competition, high reliance on IT-enabled services and the availability of a large pool of human resources have increased the sheen of IT industry in India. Software and services industry's revenue reached USD 150 Billion by 2018, by making IT Industry the largest export sector for the country (24\% of total exports). Around 100,000 new jobs are created every year, wherein the platform players and IT industry in total creates three to four times direct impact on employment. The industry is set to grow by 7-9\% from exports revenue and 10-12\% from domestic revenue. The trend for the coming years is proposed as 'cautiously positive'. The other side of this story is that the industry is spiked with high annual employee turnover rates, thereby talent management and employee retentions have become a 
major challenge for the industry (Naim \& Lenka, 2017) resulting in high talent mobility burdening the HR with the serious challenge of curtailing the high turnover rate. One of the major reasons for this high turnover is better career opportunities and benefits elsewhere (Klynveld Peat Marwick Goerdeler [KPMG], 2017). The average voluntary attrition for IT (14.5\%) and ITES (IT Enabled Services) (15.4\%) is higher than the overall national average (13.4\%) (KPMG, 2017).

\section{Participants and Procedure}

The conceptual model is empirically tested on a sample of software engineers employed in the Indian IT industry in Kochi, India. The relationship between above mentioned variables could be best captured when the population is homogenous with respect to industry, profession and educational background because different industries may have different job demands and requirements making assessments of protean career attitudes and employability perception difficult to interpret. Software employees within the private IT sector forms a more homogenous group in terms of educational background and job specifications and the opportunities available are similar across various levels of employment.

Software engineers, with minimum one year of experience were considered for the study. The survey research design has been used to explore the constructs under study. Data collection was done on both online and offline modes during the period of February-April 2018. From the completed questionnaires, only 201 were usable. The age group of respondents ranged from 22 to 48 years; the average age being 28 years. Most of the employees have 1-5 years of experience (75\%). $50.7 \%$ of respondents were single and he $63 \%$ of the respondents were graduates while $34 \%$ were postgraduates. More than half of the respondents were males (52.7\%).

\section{Data Analysis}

The initial screening was done using IBM SPSS 23. Further analysis was conducted with WARP PLS v.6.0 statistical software. Mediation analysis was done using Baron and Kenny approach (1986). The three-step model for mediation was found to be highly reliable in the management literature (Suliman, 2002) and this model is used in the study to examine the mediation hypothesis.

Initial screening of the data was done using the mean, standard deviation and the correlations table. From the descriptive statistics Table 1 it is evident that the variables under study are moderately correlated. Most of statistical analyses are 
done on the presumption of normality of data. Normality of data is assessed by analysing the kurtosis and skewness of the variables which is presented in Table 1.

Table 1: Descriptive Statistics

\begin{tabular}{llllrrrrr}
\hline Variable & IE & EE & CI & PCA & Mean & S.D & Kurtosis & Skewness \\
\hline IE & 1 & & & & 3.59 & 1.07 & 1.88 & 0.98 \\
EE & $0.50 *$ & 1 & & & 3.56 & 0.69 & 0.26 & -0.63 \\
CI & $0.50 *$ & $0.72 *$ & 1 & & 3.78 & 0.75 & -0.67 & -0.45 \\
PCA & $0.43 *$ & $0.58^{*}$ & $0.61 *$ & 1 & 3.54 & 0.78 & 1.15 & 0.76 \\
\hline
\end{tabular}

Notes: $1 . *$ denotes $p<.01$ (2-tailed)

2. IE: Internal employability; EE: External employability; CI: Career insight; PCA: Protean career attitude

The fit of the proposed model depicted in Figure 1 with the data was tested using variance based structural equation modelling (Partial Least Squares analysis) with WARP PLS v.6.0 statistical software (Kock, 2012). Constructs in each model were represented by latent factors, which are indicated by its constituent scale items, with estimated structural relations specified among constructs consistent with the proposed models.

\section{Measurement Model Analysis}

Table 2 summarises the results of the measurement model. Composite Reliability (CR), and the variance extracted were used to assess convergent validity (Fornell \& Larcker, 1981). In this study, the CR ranging from 0.764 to 0.905 exceeded the recommended level of 0.7 (Gefen et al., 2000). The Average Variance Extracted (AVE) were in the range of 0.498 to 0.827 , meeting the recommended level of 0.5 (Hair et al., 2010). Next, the discriminant validity was examined by comparing the correlation between constructs and the square root of the variance extracted for a construct (Fornell \& Larcker, 1981) and results of discriminant validity for this study shows that it is achieved because the square root of AVE for each latent variable exceeded the inter-construct correlation. Furthermore, results of the Variance Inflation Factor (VIF) (see Table 2) were in the range of 1.585 to 2.547, below the recommended level of 5 (Hair et al., 2010). The findings of the measurement model indicate that the variables used in this paper are reliable.

In addition, potential multicollinearity was checked using the Full Collinearity Variance Inflation Factor (AFVIF), and values lower than 3.30 indicates no issues with multicollinearity (Kock, 2012). 
Table 2: Measurement Model Statistics

\begin{tabular}{llcccc}
\hline Construct & Type & $\begin{array}{l}\text { No. of } \\
\text { items }\end{array}$ & CR & AVE & VIF \\
\hline $\begin{array}{l}\text { Internal } \\
\text { employability }\end{array}$ & Reflective & 4 & 0.76 & 0.49 & 2.31 \\
$\begin{array}{l}\text { External } \\
\text { employability }\end{array}$ & Reflective & 6 & 0.83 & 0.51 & 2.54 \\
$\begin{array}{l}\text { Protean career } \\
\text { attitude }\end{array}$ & Reflective & 14 & 0.90 & 0.82 & 1.58 \\
\begin{tabular}{l} 
Career Insight \\
\hline
\end{tabular} & Reflective & 7 & 0.87 & 0.50 & 2.11 \\
\hline
\end{tabular}

Considering potential interaction due to common method bias as the data is collected from a single source, Harman's single-factor test (Podsakoff et al., 2003) was conducted to inspect whether a general factor emerged and accounted for the majority of covariance among the measures. Results revealed only $30.19 \%$ of variance for a single factor and thus confirm the absence of common method bias reporting. Adequacy of the hypothesised model was established using an overall Goodness-of-Fit (GoF) index given by the square root of the product of the AVE and average $\mathrm{R}^{2}$ for the model, with values of $0.100,0.250$, and 0.360 corresponding to small, medium, and large effect sizes, respectively (Tenenhaus et al., 2005). The fit indices are discussed in detail in Table 3. All the fit indices are below the threshold limit.

Table 3: Fit Indices

\begin{tabular}{lcc}
\hline Fit Index & Value & Threshold limit \\
\hline $\begin{array}{l}\text { Average path coefficient } \\
\text { (APC) }\end{array}$ & $0.43(p<0.001)$ & $p<0.001$ \\
$\begin{array}{l}\text { Average R-squared (ARS) } \\
\text { Average adjusted R- }\end{array}$ & $0.45(p<0.001)$ & $p<0.001$ \\
squared (AARS) & $0.45(p<0.001)$ & $p<0.001$ \\
Average block VIF (AVIF) & 1.52 & acceptable if $\leq 5$, ideally $\leq 3.3$ \\
$\begin{array}{l}\text { Average full collinearity } \\
\text { VIF (AFVIF) }\end{array}$ & 2.14 & acceptable if $\leq 5$, ideally $\leq 3.3$ \\
$\begin{array}{l}\text { Tenenhaus GoF (GoF) } \\
\text { Sympson's paradox ratio } \\
\text { (SPR) }\end{array}$ & 0.49 & $0.1 \leq$ small $\leq 0.25 \leq$ medium $\leq 0.36 \leq$ large \\
\end{tabular}




\begin{tabular}{lcc}
\hline Fit Index & Value & Threshold limit \\
\hline $\begin{array}{l}\text { R-squared contribution } \\
\text { ratio (RSCR) }\end{array}$ & 1 & acceptable if $\geq 0.9$, ideally $=1$ \\
$\begin{array}{l}\text { Nonlinear bivariate } \\
\text { causality direction ratio } \\
\text { (NLBCDR) }\end{array}$ & 1 & acceptable if $\geq 0.7$ \\
$\begin{array}{l}\text { Statistical suppression ratio } \\
(\text { SSR })\end{array}$ & 1 & \\
\hline
\end{tabular}

\section{Structural Model Analysis}

The structural model represents the relationship between latent variables that were hypothesised in the research model. The coefficient of determination $\left(\mathrm{R}^{2}\right)$, predictive relevance $\left(\mathrm{Q}^{2}\right)$, effect size $(f 2)$ and path coefficient $(\beta)$ are four criteria used to assess structural model in this study. The results of this study found that predictor variables seem to have a moderate influence on the endogenous constructs. Chin and Newsted (1999) recommended $\mathrm{R}^{2}$ values for endogenous latent variables based on: 0.67 (substantial), 0.33 (moderate), 0.19 (weak). Acceptable predictive validity in connection with an endogenous latent variable is analysed by looking into the Q-squared coefficient greater than zero. Table 4 presents the results for $\mathrm{R}^{2}$ and $\mathrm{Q}^{2}$ coefficients.

Table 4: $\mathbf{R}^{2}$ and $\mathbf{Q}^{2}$ Coefficients

\begin{tabular}{cccc}
\hline $\begin{array}{c}\text { Endogenous } \\
\text { construct }\end{array}$ & $\begin{array}{c}\text { Career } \\
\text { Insight } \\
\text { (CI) }\end{array}$ & $\begin{array}{c}\text { Internal } \\
\text { employability } \\
\text { (IE) }\end{array}$ & $\begin{array}{c}\text { External } \\
\text { employability } \\
\text { (EE) }\end{array}$ \\
\hline Q-squared & 0.33 & 0.47 & 0.54 \\
R-squared & 0.34 & 0.48 & 0.54 \\
\hline
\end{tabular}

\section{Mediation Analysis}

The results reported in Tables 5 and 6 indicate that Hypotheses 1 and 2 are supported. Baron and Kenny (1986) approach is used for testing the mediation effect of career insight in the relationships between protean career attitude and perceived internal and external employability. Baron and Kenny (1986) and Judd and Kenny (1981) discussed four steps in establishing mediation relationship: In general, variable $\mathrm{M}$ is considered a mediator when several criteria are met. $\mathrm{X}$ (independent variable) significantly predicts Y (dependent variable), X significantly 
predicts $\mathrm{M}$ (Mediator), $\mathrm{M}$ significantly predicts $\mathrm{Y}$ controlling for $\mathrm{X}$, and the effect of $\mathrm{X}$ on $\mathrm{Y}$ originally observed decreases substantially when $\mathrm{M}$ is considered simultaneously. Tables 5 and 6 show the path coefficients for the mediation analysis which are obtained by running two separate models, one with mediator and one without mediator.

Table 5: Mediation Analysis- PCA-CI-EE

\begin{tabular}{lccc}
\hline Path & Path Coefficient & $\mathbf{R}^{2}$ & $\boldsymbol{p}$ \\
\hline $\mathrm{PCA} \rightarrow$ EE & 0.53 & 0.28 & $p<0.01$ \\
$\mathrm{PCA} \rightarrow$ CI & 0.58 & 0.34 & $p<0.01$ \\
$\mathrm{CI} \rightarrow$ EE & 0.62 & 0.52 & $p<0.01$ \\
$\mathrm{PCA} \rightarrow$ EE & 0.17 & 0.54 & $p<0.01$ \\
\hline CI controlled) & & & \\
\hline
\end{tabular}

Table 6: Mediation Analysis- PCA-CI-IE

\begin{tabular}{lccc}
\hline Path & Path Coefficient & $\mathbf{R}^{\mathbf{2}}$ & $\boldsymbol{p}$ \\
\hline $\mathrm{PCA} \rightarrow$ IE & 0.59 & 0.35 & $p<0.01$ \\
$\mathrm{PCA} \rightarrow$ CI & 0.58 & 0.34 & $p<0.01$ \\
$\mathrm{CI} \rightarrow \mathrm{IE}$ & 0.44 & 0.41 & $p<0.01$ \\
$\begin{array}{l}\mathrm{PCA} \rightarrow \text { IE } \\
(\mathrm{CI} \text { controlled })\end{array}$ & 0.33 & 0.48 & $p<0.01$ \\
\hline
\end{tabular}

As hypothesised (Hypotheses 1 and 2), the protean attitude was positively related to internal and external employability. Hypotheses 3 and 4 proposes the mediating role of career insight. Warp PLS was used to test the significance of a mediating effect of a variable $\mathrm{M}$, which is hypothesised to mediate the relationship between two other variables X and Y, by using Baron and Kenny's (1986) criteria. In order to do the mediation analysis, two models were built. The first model was drawn with two variables $\mathrm{X}$ (Protean career attitude) pointing at $\mathrm{Y}$ (Perceived external employability), and another model with Perceived internal employability as dependent variable $(\mathrm{Y})$, without mediation variable $(\mathrm{M})$ being included in the model. The second model was drawn with the mediating variable, Career Insight (Figure 2).The results of the mediation analysis is presented in Tables 5 and 6. From the results it is evident that both the relationship between protean career attitude and internal employability and that with external employability are partially mediated by career insight. 
Figure 2: Integrated Model

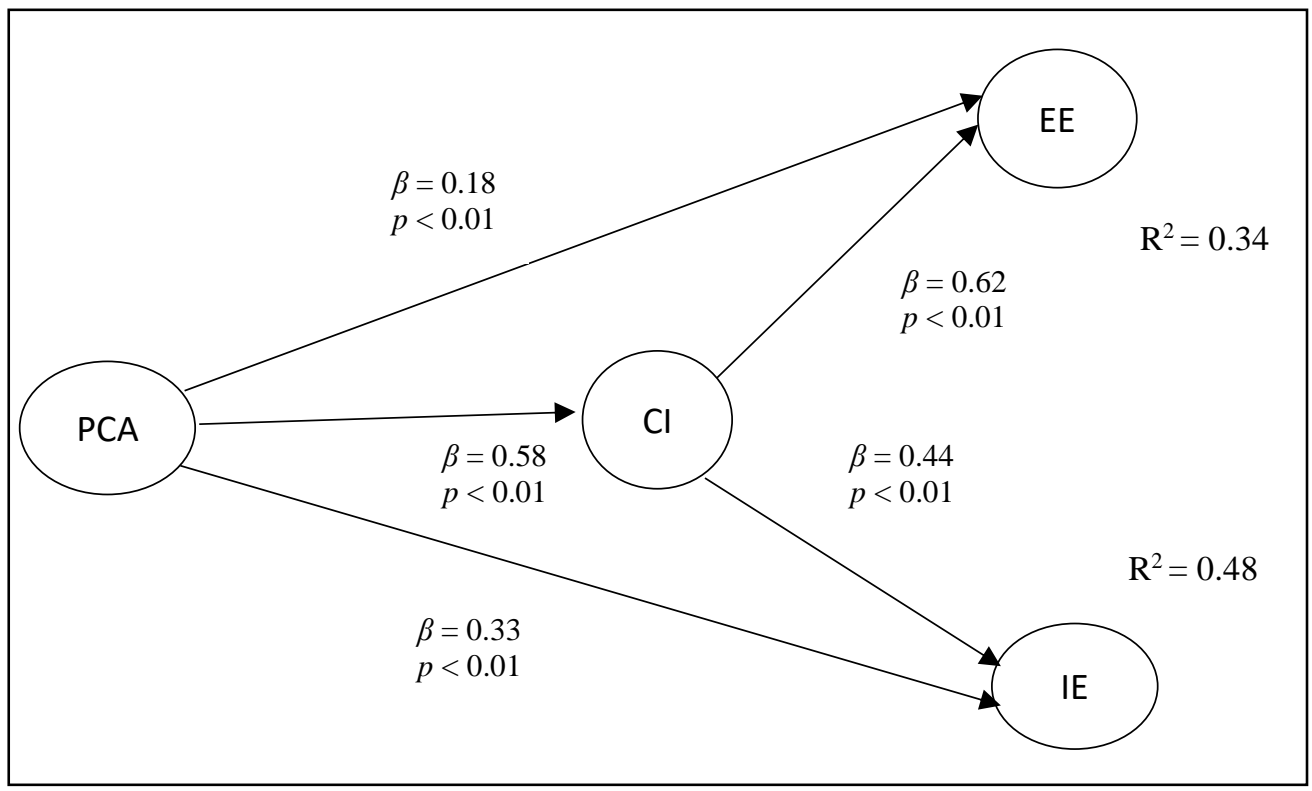

\section{Discussion}

The protean career attitude is characterised as being flexible and adaptable, and this is what motivates people in their career and career objectives in today's working environment, where careers have become highly individual specific. In analysing the impact of protean career attitude on employability the most important finding from the current study revealed that protean career attitude was a significant predictor of perceived internal and external employability. It is empirically proven that protean career attitude influences both internal and external employability. Evidence from the results show that the influence is stronger for internal employability $(\beta=0.33, p<0.01)$ rather than external employability $(\beta=0.18, p<$ 0.01). This result is consistent with prior empirical investigations (Lin, 2015; Cortellazzo et al., 2020).

The other notable result from the current study revealed that career insight partially mediated the link between protean career attitude and perceived internal employability; protean attitude and perceived external employability. The mediation analysis helps us understand the role of career insight in the relationship between protean career attitude and employability. It has become more common these days for individuals to pursue personally satisfying and fulfilling careers (protean attitude). Hence, they approach career success from a perspective of psychological 
satisfaction. Such individuals with a protean career attitude perceive a greater sense of employability because they have a better understanding of their strengths, skills, and interest (career insight), thereby becoming effective in their career management strategies.

\section{Conclusion}

In conclusion, the current study examined the association between protean career orientation and positive career outcome of employability and the intervening role of career insight in a sample of IT employees. The study findings support the prominence of new career orientation - protean career orientation - among knowledge workers and its predictive power on their internal and external employability. Theoretically, the study strengthens the significance of Job Demands - Resources theory in explaining the current career patterns and its implications on job outcomes. This paper adds empirical evidence for the presumed relevance of the protean career concept when the job market is very vibrant with opportunities. The study strengthens the notion that protean career attitude and employability perceptions (internal and external) are related (Lin, 2015). This research supports the importance of having a protean career attitude to define career fulfilment and ultimately, success. When individuals stay true to their core values and pursue careers in line with those values, they are bound to achieve greater psychological satisfaction and fulfilment enhancing their perception of employability.

Mediation analysis emphasizes the prominence of career insight in managing individual's career (De Vos \& Soens, 2008; Sultana \& Malik, 2019). The results of the mediation analysis revealed that career insight partially mediated the relationship between protean attitude and external and internal employability. These results seem to propose that career insight serves as the main buffer to influence the perceived internal employability of external employability.

Another notable outcome from the empirical analysis is that protean talents have a stronger internal employability than external employability. The results are in contrary to the general belief that protean talents have greater external employability than internal employability (Lin, 2015; Hall, 1996). This contrasting result might imply that study participants were receiving developmental support from their organisation. The employee engagement programmes, human resource development programmes provided by organisations or the employability culture prevalent in organisations could have enhanced employees' internal employability (Eby et al., 2003; Polanska, 2016). An organisation with strong employability 
culture has a huge influence on the employability orientations of employees by encouraging their personal growth (Nauta, et al., 2009) and employability (Van Dam, 2004). According to Lips-Wiersma and Hall's (2007), in modern careers, organisational and individual career management act mutually and the responsibility for career advancement is shared between the employer and the employee. Career self-management needs guidance and encouragement of the management. Contemporary knowledge workers who are encouraged to develop an active career seem to align their employability perception in line with the current organisations. These findings provide greater insight for today's organisations, to develop a sound employability culture and work infrastructure needed to enhance existing skills of employees as well as provide for marketable skills that could nurture the employability perceptions of employees.

Considering individual (employee) level outcome of developing protean attitude, it is an innovative way of enhancing one's employability perceptions in a highly complex job market. Individuals with high protean career attitude feel they are responsible for their career opportunities and are self-directed. These protean talents perform without any regular supervision and are adaptive to the changing work environment (Gulyani \& Bhatnagar, 2017). Thus, by using an appropriate strategy, the firms can influence a protean talent's perceived internal employability, which may retain them in the current organization. Employees with high protean attitude need to be given more flexibility and autonomy in their work which makes them more productive (Sullivan \& Baruch, 2009). Once protean talents try to move out in search of opportunities in line with their expectations, it will become a loss for the organisation. Organisations can facilitate career self-management behaviour by adopting a comprehensive bundle of human resource development practices (Polanska, 2016) like employee engagement programmes, human resource development programmes, and nurturing an employability culture within the organisation.

\section{Limitations and Scope for Further Research}

Our study addressed the concept of protean career attitude in a very specific sample of IT industry; the result supported the fact that such an attitude is beneficial for individuals in current career landscape that they could make use of opportunities available in the job market (Vos \& Soens, 2008). The study has some limitations in its approach, and most can be converted into further scope for research. The data used were cross-sectional. The data was collected during the time period of February 2018, and the labour market conditions prevalent during the period would 
have affected the results. Further research could enrich this area by carrying out similar study during a period of recession or when the job market is not that promising. There is also scope for conducting a longitudinal study in the same industry or across different industries to further cement the observations and unravel the relationship between the variables under study. An interesting venue for future research is to include objective career outcomes of this protean attitude; i.e., to see whether this perception on external employability leads to employer switching. Yet another scope is to look into probable interaction effect of career management practices along with career management behaviours on protean attitude and whether that could lead to enhanced internal or external employability.

\section{Declaration of Conflict of Interest}

The authors declared no potential conflict of interest with respect to the research, authorship, and publication of this article.

\section{Reference}

Bakker, A. B., \& Demerouti, E. (2007). The job demands-resources model: State of the art. Journal of Managerial Psychology, 22(3), 309-328. https://doi.org/10.1108/02683940710733115

Baron, R. M., \& Kenny, D. A. (1986). The moderator-mediator variable distinction in social psychological research: Conceptual, strategic, and statistical considerations. Journal of Personality and Social Psychology, 51(6), 11731182. https://doi.org/10.1037/0022-3514.51.6.1173

Berntson, E. (2008). Employability perceptions: Nature, determinants, and implications for health and well-being (Doctoral dissertation). Psykologiska institutionen. http://www.diva-portal.org/smash/get/diva2:198489/FULLTEXT 01.pdf

Briscoe, J. P., \& Hall, D. T. (2006). The interplay of boundaryless and protean careers: Combinations and implications. Journal of Vocational Behavior, 69(1), 4-18. https://doi.org/10.1016/j.jvb.2005.09.002

Briscoe, J. P., Hall, D. T., \& DeMuth, R. L. F. (2006). Protean and boundaryless careers: An empirical exploration. Journal of Vocational Behavior, 69(1), 3047. https://doi.org/10.1016/j.jvb.2005.09.003

Chen, D. J., \& Lim, V. K. (2012). Strength in adversity: The influence of psychological capital on job search. Journal of Organizational Behavior, 33(6), 811-839. https://doi.org/10.1002/job.1814 
Chin, W. W., \& Newsted, P. R. (1999). Structural equation modeling analysis with small samples using partial least squares. In R. H. Hoyle (Ed.), Statistical strategies for small sample research (pp. 307-341). Sage.

Clarke, M. (2008). Understanding and managing employability in changing career contexts. Journal of European Industrial Training,32(4), 258-284. https://doi.org/10.1108/03090590810871379

Cortellazzo, L., Bonesso, S., Gerli, F., \& Batista-Foguet, J. M. (2020). Protean career orientation: Behavioral antecedents and employability outcomes. Journal of Vocational Behavior, 116, 103-343, https://doi.org/10.1016/j.jvb.2019. 103343

De Cuyper, N., Van der Heijden, B. I. J. M., \& De Witte, H. (2011). Associations between employability and employee and organizational outcomes: A matter of psychological contracts? International Journal of Human Resource Management, 22(7), 1486-1503. https://doi.org/10.1080/09585192.2011. $\underline{561962}$

De Vos, A., \& Soens, N. (2008). Protean attitude and career success: The mediating role of self-management. Journal of Vocational Behavior, 73(3), 449-456. https://doi.org/10.1016/j.jvb.2008.08.007

Eby, L. T., Butts, M., \& Lockwood, A. (2003). Predictors of success in the era of the boundaryless career. Journal of Organizational Behavior, 24(6), 689-708. https://doi.org/10.1002/job.214

Fornell, C., \& Larcker, D. F. (1981). Evaluating structural equation models with unobservable variables and measurement error. Journal of Marketing Research, 18(1), 39-50. https://doi.org/10.1177/002224378101800104

Gefen, D., Straub, D., \& Boudreau, M. C. (2000). Structural equation modelling and regression: Guidelines for research practice. Communications of the Association for Information Systems, 4. https://doi.org/10.17705/1CAIS.00407

Groot, W., \& De Brink, H. M. V. (2000). Education, training and employability. Applied Economics, 32(5), 573-581. https://doi.org/10.1080/ $\underline{000368400322471}$

Gulyani, G., \& Bhatnagar, J. (2017). Mediator analysis of passion for work in Indian millennials: Relationship between protean career attitude and proactive work behavior. Career Development International, 22(1), 50-69. https://doi.org/10.1108/CDI-04-2016-0057

Gubler, M., Arnold, J., \& Coombs, C. (2014). Reassessing the protean career concept: Empirical findings, conceptual components, and measurement. Journal of Organizational Behavior, 35(S1), 23-40. https://doi.org/10.1002/job.1908

Hair, J. F., Black, W. C., Babin, B. J., \& Anderson, R. E. (2010). Multivariate data analysis: A global perspective ( $7^{\text {th }} \mathrm{ed}$.). Pearson. 
Hall, D. T. (1996). Protean careers of the $21^{\text {st }}$ century. Academy of Management Perspectives, 10(4), 8-16. https://doi.org/10.5465/ame.1996.3145315

Hall, D. T. (2002). Careers in and out of organizations. Sage.

Hall, D. T. (2004). The protean career: A quarter-century journey. Journal of Vocational Behavior, 65(1), 1-13. https://doi.org/10.1016/j.jvb.2003.10.006

Hall, D. T., \& Moss, J. E. (1998). The new protean career contract: Helping organizations and employees adapt. Organizational Dynamics, 26(3), 22-37. https://doi.org/10.1016/S0090-2616(98)90012-2

Joseph, D., Boh, W. F., Ang, S., \& Slaughter, S. A. (2012). The career paths less (or more) travelled: A sequence analysis of IT career histories, mobility patterns, and career success. MIS Quarterly, 36(2), 427 -462. https://doi.org/10.2307/ 41703462

Judd, C. M., \& Kenny, D. A. (1981). Process analysis: Estimating mediation in treatment evaluations. Evaluation Review, 5(5), 602-619. https://doi.org/ 10.1177/0193841X8100500502

Juhdi, N., Pa'Wan, F., Othman, N. A., \& Moksin, H. (2010). Factors influencing internal and external employability of employees. Business and Economics Journal, 11, 1-10.

Khan, M. L., Salleh, R., \& Hemdi, M. A. B. (2016). Effect of protean career attitudes on organizational commitment of employees with moderating role of organizational career management. International Review of Management and Marketing, 6(4S), 155-160.

Kiong, T. P., \& Yin-Fah, B. C. (2016). Exploring factors towards career success in Malaysia. International Business Management, 10(17), 3936-3943. https://doi.org/10.36478/ibm.2016.3936.3943

Kirves, K. E. (2014). Perceived employability. Antecedents, trajectories and wellbeing consequences (Doctoral dissertation). University of Tampere and University of KU Leuven. https://lirias.kuleuven.be/1963479?limo=0.

Kock, N. (2012). WarpPLS 5.0 user manual. Laredo, TX: ScriptWarp Systems.

Klynveld Peat Marwick Goerdeler (March 2017). India's annual compensation trends survey 2017-18. https://assets.kpmg/content/dam/kpmg/in/pdf/2017/03/ KPMG-Annual-Compensation-Trends-Survey-2017.pdf.

Li, Y., (2018). Linking protean career orientation to well-being: The role of psychological capital. Career Development International, 23(2), 178-196, https://doi.org/10.1108/CDI-07-2017-0132

Lin, Y. C. (2015). Are you a protean talent? The influence of protean career attitude, learning-goal orientation and perceived internal and external 
employability. Career Development International, 20(7), 753-772. https://doi.org/10.1108/CDI-04-2015-0056

Lips-Wiersma, M., \& Hall, D. T. (2007). Organizational career development is not dead: A case study on managing the new career during organizational change. Journal of Organizational Behavior, 28(6), 771-792. https://doi.org/10.1002/ job.446

London, M. (1993). Relationships between career motivation, empowerment and support for career development. Journal of Occupational and Organizational Psychology, 66(1), 55-69. https://doi.org/10.1111/j.2044-8325.1993.tb00516.x

Mincer, J. (1991). Education and unemployment (No. w3838). National Bureau of Economic Research.

Mithas, S., \& Krishnan, M. S. (2008). Human capital and institutional effects in the compensation of information technology professionals in the United States. Management Science, 54(3), 415-428. https://doi.org/10.1287/mnsc. 1070.0778

Naim, M. F., \& Lenka, U. (2017). Talent management: a burgeoning strategic focus in Indian IT industry. Industrial and Commercial Training, 49(4), 183-188. https://doi.org/10.1108/ICT-12-2016-0084

Nauta, A., Van Vianen, A., Van der Heijden, B., Van Dam, K., \& Willemsen, M. (2009). Understanding the factors that promote employability orientation: The impact of employability culture, career satisfaction, and role breadth selfefficacy. Journal of Occupational and Organizational Psychology, 82(2), 233251. https://doi.org/10.1348/096317908X320147

Ngo, H. Y., Liu, H., \& Cheung, F. (2017). Perceived employability of Hong Kong employees: Its antecedents, moderator and outcomes. Personnel Review, 46(1), 17-35. https://doi.org/10.1108/PR-01-2015-0015

Noe, R. A., Noe, A. W., \& Bachhuber, J. A. (1990). An investigation of the correlates of career motivation. Journal of Vocational Behavior, 37(3), 340 356. https://doi.org/10.1016/0001-8791(90)90049-8

Ortega, J. (2001). Job rotation as a learning mechanism. Management Science, 47(10), 1361-1370. https://doi.org/10.1287/mnsc.47.10.1361.10257

Paradnike, K., Endriulaitiene, A., \& Bandzeviciene, R. (2016). Career selfmanagement resources in contemporary career frameworks: A literature review. Organizacijф Vadyba: Sisteminiai Tyrimai, 76, 91-106. https://doi.org/10.7220/MOSR.2335.8750.2016.76.6

Podsakoff, P. M., MacKenzie, S. B., Lee, J. Y., \& Podsakoff, N. P. (2003). Common method biases in behavioral research: A critical review of the 
literature and recommended remedies. Journal of Applied Psychology, 88(5), 879-903. https://doi.org/10.1037/0021-9010.88.5.879

Polanska, M. A. (2016). An empirical investigation of career self-management behaviours: test of a theoretical model (Master's dissertation). Lisbon University Institute). https://repositorio.iscte-iul.pt/handle/ 10071/13784

Redondo, R., Sparrow, P., \& Hernández-Lechuga, G. (2019). The effects of protean careers on talent retention: Examining the relationship between protean career orientation, organizational commitment, job satisfaction and intention to quit for talented workers. The International Journal of Human Resource Management. Advance online publication. https://doi.org/10.1080/09585192.2019.1579247

Rodrigues, R., Butler, C. L., \& Guest, D. (2019). Antecedents of protean and boundaryless career orientations: The role of core self-evaluations, perceived employability and social capital. Journal of Vocational Behavior, 110, 1-11. https://doi.org/10.1016/j.jvb.2018.11.003

Rothwell, A., \& Arnold, J. (2007). Self-perceived employability: Development and validation of a scale. Personnel Review, 36(1), 23-41. https://doi.org/10.1108/ $\underline{00483480710716704}$

Soumyaja, D., Kamalanabhan, T. J., \& Bhattacharyya, S. (2018). Antecedents of employee readiness for change in the IT sector and the manufacturing sector: A comparative study. International Journal of Human Resources Development and Management, 18(3-4), 237-256. https://doi.org/10.1504/IJHRDM.2018. $\underline{093444}$

Suliman, A. M. (2002). Is it really a mediating construct? The mediating role of organizational commitment in work climate-performance relationship. Journal of Management Development,21(3), 170-183. https://doi.org/10.1108/ $\underline{02621710210420255}$

Sullivan, S. E., \& Baruch, Y. (2009). Advances in career theory and research: A critical review and agenda for future exploration. Journal of Management, 35(6), 1542-1571. https://doi.org/10.1177/0149206309350082

Sultana, R., \& Malik, O. F. (2019). Is Protean career attitude beneficial for both employees and organizations? Investigating the mediating effects of knowing career competencies. Frontiers in Psychology, 10, 1-13. https://doi.org/ 10.3389/fpsyg.2019.01284

Tenenhaus, M., Vinzi, V. E., Chatelin, Y. M., \& Lauro, C. (2005). PLS path modeling. Computational Statistics \& Data Analysis,48(1), 159-205. https://doi.org/10.1016/j.csda.2004.03.005

Upadhyay, P., Singh, R., Jahanyan, S., \& Nair, S. (2016). Measuring the effects of role efficacy enhancement on knowledge workers: Evidence from Indian IT 
industry. International Journal of Productivity and Performance Management, 65(6), 860-872. https://doi.org/10.1108/IJPPM-03-2016-0065

Van Dam, K. (2004). Antecedents and consequences of employability-orientation. European Journal of Work and Organizational Psychology, 13(1), 29-51. https://doi.org/10.1080/13594320344000237

Vanhercke. D, De Cuyper, N., Peeters, E., \& De Witte, H. (2014). Defining perceived employability: A psychological approach, Personnel Review, 43(4), 592-605. https://doi.org/10.1108/PR-07-2012-0110

Volmer, J., \& Spurk, D. (2011). Protean and boundaryless career attitudes: Relationships with subjective and objective career success. Zeitschrift für Arbeitsmarkt Forschung, 43(3), 207-218. https://doi.org/10.1007/s12651-010$\underline{0037-3}$

Waters, L., Briscoe, J. P., Hall, D. T., \& Wang, L. (2014). Protean career attitudes during unemployment and reemployment: A longitudinal perspective. Journal of Vocational Behavior, 84(3), 405-419. https://doi.org/10.1016/j.jvb.2014. $\underline{03.003}$ 